\title{
THE LITHUANIAN NOBILITY IN THE LATE- FOURTEENTH AND FIFTEENTH CENTURIES: COMPOSITION AND STRUCTURE
}

\author{
RIMVYDAS PETRAUSKAS
}

ABSTRACT This paper presents a critical review of the historiographically dominant theory stating that the upper layer of the Lithuanian nobility formed its independent power only around the middle of the fifteenth century. The extant sources shed little light on the role of the nobility in the political processes of the thirteenth and fourteenth centuries. A complex of sources, more fully reflecting the specifics of the country, appeared only after the arrival of writing in Lithuania at the end of the fourteenth century. It was only in this period that the place of the nobles in the system of government became evident. Therefore, it is possible to speak about a distorted perspective, suggested by the early records. The paper presents a definition of the nobility and an analysis of the origin, composition and structure of the Lithuanian ruling élite in the late fourteenth and fifteenth centuries. Consequently it is possible to speak about the prerequisites of the rule of this social group and the duality of the power of the grand duke and the nobility. Two principal tendencies of the development of the Lithuanian nobility in the fifteenth century personal continuity and internal transformation (family structure) - are distinguished.

In Lithuanian historical models the fourteenth and fifteenth centuries have acquired the image of the epoch of 'ducal Lithuania'. This was a period of the rule of the grand dukes Gediminas, Algirdas, Kęstutis, Jogaila and Vytautas. Therefore, these models are justified to some extent, since in the Middle Ages the ruler personified the state proper. The state was treated as the sovereign's patrimony, and all its inhabitants were his subjects. This theoretical model of the epoch was used as an explanatory conception. A strict chronological boundary marking the 'primary' rule of the grand dukes was drawn, and subsequently one more date, designating the rule of the nobility and 'delimiting' or 'supplementing' the ruler's authority, was recognized. Therefore, investigating the early society of Lithuania, researchers focused their attention on the rule of the 
sovereigns, while the history of the nobility, despite several important works, was dealt with only superficially. Nevertheless, the social and political history of Lithuania can be interpreted as a form of the duality of monarchy and nobility. ${ }^{1}$ To understand the roots of this duality it is necessary to look into the internal development of the Lithuanian nobility.

The argument that the gradual redistribution of the internal political influence began in the mid-fifteenth century after the union with Poland and the baptism of Lithuania became strongly entrenched in Lithuanian historical scholarship. The charters of grand dukes from Jogaila in 1387 to Aleksandras Jogailaitis (Alexander Jagiellończyk) in 1492 conferred the right of deciding the principal issues of the country on the high nobility and later on its political institution, the Council of Lords. The rule of the grand duke was gradually replaced by the powers of the recently arisen nobility. This model, logical and irreproachable at first sight, is grounded on the data of legal sources, mainly the texts of the charters themselves. The institutionalization of the social élite is attributed to the appearance of estate privileges, which, in their turn, are interpreted in the context of the social policy of Vytautas the Great (1392-1430) and Polish institutional influence after the Treaty of Horodło (1413). ${ }^{2}$

1 This is also supported by research on the history of Western European nations: K. Schmid, Geblüt, Herrschaft, Geschlechterbewusstsein: Grundfragen zum Verständnis des Adels im Mittelalter (Sigmaringen, 1998; habilitation dissertation, 1961); K. F. Werner, 'Bedeutende Adelsfamilien im Reich Karls des Großen', Karl der Grosse: Lebenswerk und Nachleben, vol. 1, ed. H. Beumann (Düsseldorf, 1965), p. 84; G. Tellenbach, 'Zur Erforschung des mittelalterlichen Adels (9-12. Jahrhundert)', XII Congrès international des sciences historiques. Rapports, t. 1 (Vienna, 1965), pp. 318-337; L. Genicot, La noblesse dans l'Occident médiéval (London, 1982); O. G. Oexle, 'Aspekte der Geschichte des Adels im Mittelalter und in der Frühen Neuzeit', Europäischer Adel 1750-1950, ed. H.-U. Wehler (Göttingen, 1990), pp. 19-56; M. Borgolte, Sozialgeschichte des Mittelalters (Munich, 1996), pp. 190-218. On the place of the gentry in Central Eastern Europe, see F. Graus, 'Die Entstehung der mittelalterlichen Staaten in Mitteleuropa', Historica, 10 (1965), pp. 5-65.

2 (1) The so-called Vytautas' centralization policy: the replacement of Gediminid dukes by noble lieutenants. (2) The Treaty of Horodło enabled 47 Lithuanian noble families to obtain Polish coats of arms, thus becoming influential in the political life of the country. Interestingly, Lithuanian historical scholarship is more liable to stress the first aspect, i.e., the centralization policy; cf. K. Avižonis, Die Entstehung und Entwicklung des litauischen Adels bis zur litauisch-polnischen Union 1385 (Berlin, 1932), pp. 140-155; Z. Ivinskis, Geschichte des Bauernstandes in Litauen. Von den ältesten Zeiten bis zum Anfang des 16. Jahrhunderts (Berlin, 1933), pp. 94-95; B. Dundulis, Lietuvos kova dèl valstybinio savarankiškumo XV amžiuje (Vilnius, 1993, 2nd ed.), pp. 39-40. Meanwhile, Polish historians see 
The scarcity of sources does not properly display the role of the nobility in the political processes of the thirteenth and fourteenth centuries. It was only in the late fourteenth century that a complex of sources developed after the arrival of writing in Lithuania to record the situation of the country more exhaustively. This period marks the beginning of the influence of the nobility in the system of government. The rising power of the nobility is usually associated with the following phenomena: (1) the union with Poland and the reception of Polish legal institutes; (2) a new social and political structure created by Vytautas as a counterpoise to the power of the hereditary rulers within the Grand Duchy, who are known as udel'nye kniazi in Russian scholarly tradition, and (3) the fifteenthcentury struggles of the dukes for power and respective concessions for the nobility.

Such a 'ruler-centric' perception of early Lithuanian history is very old, and possibly it would be not a mistake to claim that it is the same secularized variant of medieval historiography that treats history as a sequence of the successes and failures of the ruler. That means that our perception of the past is conditioned to a considerable degree by the self-opinion expressed by society, or at least some of its representatives, in past times. To some extent, this is necessary, but in some cases it can lead to a one-sided interpretation of reality. Of major significance is the fact that our knowledge about pre-Christian Lithuania is based only on foreign chronicles, which are both interesting and problematic sources. Lithuania's situation is complicated further by the very late formation of its own historical writings. It should be taken into account that the work of the authors from other countries was influenced by the existence of certain (mainly military) interests and by their limited information sources. Dealing with Lithuania, they usually mentioned only the dukes, their military campaigns, internal quarrels, etc., ignoring the circumstances of those events and their many participants.

the significance of the Treaty in the fact that a group of the entire nobility was selected to become progenitors of the future families of magnates; cf. W. Semkowicz, 'Braterstwo szlachty polskiej z bojarstwem litewskim w unji horodelskiej 1413 roku', Polska $i$ Litwa $w$ dziejowym stosunku (Cracow, etc. 1919), pp. 394-446; O. Halecki, Dzieje Unii Jagiellońskiej, vol. 1 (Cracow, 1919), pp. 252-263; K. Pietkiewicz, Wielkie Księstwo Litewskie pod rzqdami Aleksandra Jagiellończyka (Poznań, 1995), p. 81; L. Korczak, Litewska rada wielkoksiqżęca w XV wieku (Cracow, 1998), p. 18. 
This particular characteristic of the historical record suggests that a certain important part of the past is not covered by any records or their allusions and that the power relationship between the grand duke and the nobility was far more complicated than is revealed by the sovereign's charters. In view of the absence of established state structures, the dukes themselves had to look for people to implement their political programmes. The only real force capable of participating in the solution of government problems was the nobility. The relations between the dukes and the nobility were a regular phenomenon in a society, where power depended on personal relationships. To be at the helm of state one had to have a large backing. In the circumstances of constant struggles for the throne, the chances of a particular candidate depended on the sympathies of the nobility, which had to be won and protected. The theory of 'a strong duke and a weak nobility' is controversial and cannot explain the mechanism of the implementation of power. ${ }^{3}$

In this respect, the investigation of the social and political status of the nobility is of major importance. First, it is necessary to present a critical analysis of the prevailing theory, according to which the high Lithuanian nobility shaped its independent power only around the middle of the fifteenth century. Second, prosopographical research into the Lithuanian nobility is possible only starting with the end of the fourteenth century.

The following issues are essential in an analysis of the presumptions of the rule of the nobility: (1) the origins of the noblemen of Vytautas' time, (2) nobility land-owning, (3) the genealogical continuity of the ruling élite in the fifteenth century, (4) the prerequisites of the authority of officials, and (5) the kinship structure of the nobility.

The term 'nobility' is problematical, and its use must be substantiated separately. This terminological difficulty is related to the medieval social structure and its reflection in the consciousness of the people of that time. The historian is confronted with three levels of that reflection: the social reality of society, the perception of that reality by the people of that day and the modern interpretation

${ }^{3}$ The fact that the nobility understood the importance of its own power is attested by the speech of its representatives, retold in the collection of the acts of the Teutonic Order relating to the year 1430: 'Dye herren von Lyttawen unde Rewsen goben vor, das sye von angenge unde y weren freye herren gewest, eynen grosfursten sye voe eren herren hylden, wen der abegynge, sye eyn andern mochten yrwelen, den eren herren welden halden'. Scriptores Rerum Prussicarum (hereafter $S R P$ ), ed. T. Hirsch, M. Töppen, E. Strehlke, III (Leipzig, 1866), p. 493. 
of that reality. ${ }^{4}$ Therefore, social reality and its concurrent reflection are different aspects of the same problem.

In the fourteenth and early fifteenth century the life of Lithuanian noblemen was not recorded in writing, and their selfconsciousness can only be reconstructed on the basis of the descriptions of other people, often belonging to other societies. The analysis of social terminology is very informative. At the turn of the fourteenth century the most usual terms designating the nobles were nobiles and bayoren. Edvardas Gudavičius' remark about the use of the latter word in the chronicles of the Teutonic Order in its Lithuanian form suggests that it was commonplace in everyday usage. ${ }^{5}$ It was the most general key term to refer to the nobles. The chronicles of the Order contain some more terms meliores, proceres, satrapae, nobiles satrapae, and even meliores satrapae. The chroniclers seem to have intended to signify the differences in the social status of the nobles by varying the terms. That, however, does not mean the opposition of the nobles to 'ordinary' boyars, since both nobiles and bayoren could stand for both categories. It is impossible to speak about a separate estate of the nobles. Nor could the actual differences between the upper and the lower nobility be ignored. Therefore, it could be surmised that there existed a social layer, endowed with the functions of government; its representatives occupied the highest posts, they were members of the grand duke's council, and they possessed large estates. Namely this layer is the object of this study.

The very idea of a 'bayoren estate' is problematical. It is an element, peculiar at least to the thinking of the Christian Middle Ages and dividing society into three estates - tres ordines / tria genera hominum - oratores, bellatores and laboratores, 'those who pray, those who fight and those who labour'. In the Middle Ages the simplest and most popular task of social stratigraphy was the definition of the duties of the members of each stratum. The most prominent theoreticians of this idea were Adalbert de Laon and Gérard de Cambrai, who were concerned to rally the entire Christian community in those tumultuous times; their texts go back to the

${ }^{4}$ O. G. Oexle, 'Deutungsschemata der sozialen Wirklichkeit im frühen and hohen Mittelalter. Ein Beitrag zur Geschichte des Wissens', Mentalitäten im Mittelalter. Methodische und inhaltliche Probleme, ed. F. Graus (Sigmaringen, 1987), p. 68.

${ }^{5}$ E. Gudavičius, 'Šlèktu atsiskyrimas nuo bajorų Lietuvoje XVI a. (Bajoru luomo susidarymas XV a.)', Lietuvos TSR Mokslu Akademijos darbai. Serija A, 2 (1975), p. 98. 
early eleventh century. Historians have discussed at length whether it was merely a theoretical model and to what extent it corresponded to social reality at that time. In any case, it is generally accepted as a scheme, which facilitated the structuring of a rather variegated social reality. ${ }^{6}$ In Lithuania theoretical deliberations of this kind appeared much later. One of the first to present a comprehensive, slightly modified variant of the theory of 'three estates' was Andrius Volanas (c. 1530-1610). ${ }^{7}$

A theoretical and legal conception of the estate reached Lithuania together with Christianity. Its first traces are evident in the earliest charters of the grand dukes. ${ }^{8}$ These charters, however, do not yet prove the reception of the theory. It is doubtful whether in the fourteenth and fifteenth centuries the Lithuanian nobility perceived themselves as representatives of a certain integral estate. Applying the term 'estate' to them would ignore the essential principles of identification. To identify themselves in the case of necessity, they used such formulas as haeres, filius, or de, thus disclosing their lineage priorities. ${ }^{9}$ The basis of their noble superiority was ancestral rather than estate dependence. Thus, there is no principle of estate equality in their relations. Nobility cannot be singular and individual, it is inherited, and it can vary in degree: nobilis, nobilior, nobilissimus. Thus, as early as the sixteenth century, Albertas Goštautas speaks about the higher nobility of his family, the degree of which is attested by the position of his relatives. ${ }^{10}$

This conclusion suggests a search for a different interpretation of the concept 'nobility'. Perhaps it is the motif of lineage that expresses its content best. The concept of noble status is logical

${ }^{6}$ In more detail, see O. G. Oexle, 'Die funktionale Dreiteilung der “Gesellschaft” bei Adalbero von Laon', Frühmittelalterliche Studien, 12 (1978), pp. 1-54; S. Russocki, 'Średniowieczne kondycje i stany', Spoleczeństwo Polski średniowiecznej, 3 (1985), pp. 189-218.

${ }^{7}$ A. Volanas, Rinktiniai raštai, ed. M. Ročka and I. Lukšaitè (Vilnius, 1996), p. 65. In greater detail, see R. Petrauskas, 'Luomai', Lietuvos Didžiosios Kunigaikštijos kultūra: tyrinejimai ir vaizdai (Vilnius, 2001), p. 320.

${ }^{8} \mathrm{Cf}$. the document, issued by Jogaila in relation to baptism on 22 February 1387: 'omnes nacione Lithvanos utriusque sexus, cuiuscunque status, condicionis aut eminecie' (my emphasis), Kodeks dyplomatyczny katedry i diecezji wileńskiej (henceforth $K D K D W$ ), ed. J. Fijałek and W. Semkowicz (Cracow, 1932-1948), p. 13.

${ }^{9} \mathrm{Cf}$. the donation documents in $K D K D W$, in which the titling of the noblemen shows that the custom to indicate the post and other social attributes next to origin appeared comparatively late.

${ }^{10}$ R. Jasas, 'Lietuvos kanclerio Alberto Goštauto memorialas karalienei Bonai (1525)', Vilniaus universiteto bibliotekos metraštis (Vilnius, 1972), p. 233; also reprinted in: Šešioliktojo amžiaus raštija (Vilnius, 2000), p. 33. 
only in the context of lineage. A boyar is a member of a family, distinguished by certain traits and a certain status. Legal differences were not the only and far from being dominating estate characteristics in that society. The homogeneous noble estate, defined in the early charters and law codes, was very diverse internally. Real socio-political difference in the importance of separate individuals and families produced a rather heterogeneous picture of social relations. Among the nobility there appeared a group of people, who performed important functions of government due to influential parents, successful marriages or proximity to the ruler. The ruler, in his turn, could influence distribution of rank within that group; however, he could not radically change its composition. Instead, it would be possible to speak about a mechanism of a 'spontaneous' renewal of the élite layer, e.g., by changing one's status through marriage. These people distanced themselves from other nobles (nobiles, boiare) by indicating their social status - dominus, magnificus, pan - next to the indication of their origin in the documents. Therefore, one could speak reasonably about the social differentiation within the nobility. That was not defined legally, but judicial barriers are not the only indicators of the differentiation of social groups. In the fifteenth century the Lithuanian nobility had already entered the path of the estate formation. That process was conditioned both by the internal development of Lithuanian society and the new conception of the estate framed under Western and Christian influence.

In the fifteenth century the Lithuanian nobility was not a homogeneous structure, and the rise of a new social group - the service gentry - still further deepened its differentiation. Semantically this segregation is marked by the fact that in the latter half of the fifteenth century the magnates did not title themselves 'boyars' any more.

Origins Historians usually attribute the rise of a social group, differing from the general mass of the nobility by its influence and status, with Vytautas' rule. The socio-political strengthening of the high nobility is associated with the alleged weakening of the ruler's authority after Vytautas' death. ${ }^{11}$ The beginnings of this theory go back to the early twentieth century when Matvei Liubavskii

11 J. Suchocki, 'Formowanie się i skład narodu politycznego w Wielkim Księstwie Litewskim', Zapiski Historyczne, 48 (1983), pp. 31-78; E. Banionis, 'Lietuvos bajorai 1413 m. Horodleje', Žalgirio laiku Lietuva ir jos kaimynai (Vilnius, 1993), pp. 189-203; Pietkiewicz, Wielkie Księstwo Litewskie, p. 81. 
constructed his model of the genesis of Lithuanian parliamentarianism. ${ }^{12}$ The criticism of this theory should begin with the investigation of the origin of the nobles of Vytautas' time, or to put it differently, with the search for the parents of those noblemen.

This research is complicated by the issues related to historical sources. The point is that the names of Lithuanian boyars are recorded only in several chronicles of the Teutonic Order and international treaties. Another problem is the system of names in pagan Lithuania. Like people in other countries of a similar level of development, the Lithuanians had only one name, and in contrast with some other countries, that name was not hereditary; neither was there a principle of variant name formation. On the whole, even if there existed any logic of naming, the present state of the knowledge of that period does not reveal it. Therefore, in the absence of any additional data, it is usually impossible to disclose the early genealogical ties between historical personalities. In this situation there is no way of establishing the progenitors of the future famous families among the nobles of Gediminas' or Algirdas' times. At the same time it is equally impossible to prove the credibility of the statements about the demise or rise of particular families, which is sometimes perceived as an unmistakable fact. Even in those rare cases when the sources indicated that a certain person died heirless, it was quite plausible that the parentage was continued on the side of the uncles and nephews. At best it is possible to determine, observing methodological rigidity, whether the most influential figures or their parents of Vytautas' time could be encountered earlier as well. A positive answer would witness an aristocratic structure of the Lithuanian nobility in 'the ducal era'.

Research into the most prominent noblemen of Vytautas' epoch shows that their high status could be accounted for by their descent. Without going into details, it can be stated that the parents of all of them belonged to the then ruling élite. ${ }^{13}$ Therefore, it would be pointless to regard those noblemen as descendants of the middling or service boyars, let alone the formation of a new social layer on Vytautas' initiative. It is worth noting that Vytautas' epoch was in no way extraordinary in the tradition of the most famous families, in contrast to the petty nobility for the majority of whom Vytautas'

${ }_{12}$ M. K. Liubavskii, Litovsko-russkii seim (Moscow, 1900).

${ }^{13}$ In more detail, see R. Petrauskas, 'Vytauto laikų didikų kilmè', Lituanistica, 2000, 1-2, pp. 16-31. 
privileges were the principal legitimacy of their status. ${ }^{14}$ Neither do the earliest historiographical records - Lithuanian chronicles contain any traces of reforms which could have affected the highest layer of the nobility.

Investigation of the problems of nobility's landowning was influenced by a significant work of Henryk Łowmiański. In his opinion, the land-ownership of a boyar of Vytautas' time was a village. ${ }^{15}$ One could agree with Łowmiański that Vytautas' rule contributed to the formation of large-scale land holding. Nevertheless, it was not only the ruler's charters that shaped the material basis of the nobility's power. A closer reading of the documents would reveal that a formal recognition of already existing noble land-ownership lay behind the numerous donations of the grand duke. According to the sources, in early-sixteenth-century Lithuania there existed a rather complicated system of land holding, which could not be expressed by the formula 'one boyar - one village'. ${ }^{16}$ A characteristic feature of the patrimonial holdings was their topographical dispersal. The nobles' land holdings were scattered in various parts of the country, which corresponded to the interrelated structure of the family. Such an order of landowning enabled the nobility to ensure its influence in various parts of the state. In view of the absence of archaeological investigations it is difficult to reconstruct the internal structure of these land holdings. The land grants of the fifteenth century indicate only the presence of churches in the estates of the nobles.

It is also impossible to establish the right of the grand duke in respect to the landowning of the nobility. According to some

${ }^{14}$ There are many documents of the late fifteenth and sixteenth centuries, in which petty boyars assert their noble origin resorting to charters granted by Vytautas to their ancestors.

15 H. Łowmiański, Studia nad poczatkami spoleczeństwa i państwa litewskiego, vol. 1-2 (Vilnius, 1931-1932). Also cf. works, dealing with the appearance of separate large estates in Lithuania: J. Glinka, 'Ród Klausucia w wiekach XIII-XVI. Ze studiów nad kszałtowaniem się i różnicowaniem społecznym bojarstwa litewskiego', Studia Źródłoznawcze, 4 (1959), pp. 85-107; 5 (1960), pp. 35-55; W. Peltz, 'Ród Giedygołda i jego majętności. Z dziejów tworzenia się wielkiej własności ziemskiej w Wielkim Księstwie Litewskim w XV wieku', Zeszyty Naukowe Uniwersytetu im. A. Mickiewicza, Historia, 11 (1971), pp. 23-44; K. Pietkiewicz, Kieżgajłowie i ich latyfundium do połowy XVI wieku (Poznań, 1982); M. Malczewska, Latyfundium Radziwitłów w XV do połowy XVI wieku (Warsaw-Poznań, 1985); E. Kelma, 'Ród Sakowiczów i jego majętności w XV i pierwszej połowie XVI wieku', Lituano-Slavica Posnaniensia: Studia Historica, 3 (1989), pp. 155-177.

16 Petrauskas, 'Vytauto laikų didikų kilmè', pp. 22-25. 
sources, the forfeiture of patrimonial lands was considered unlawful. ${ }^{17}$

One further indicator of the socio-political significance of the nobility is the continuity noticeable within the composition of the ruling élite. The most valuable source, furnishing related information is the lists of witnesses in the ruler's documents, the so-called testationes. The abundance of such documents, observed in the late fourteenth century, makes possible conclusions more reliable. ${ }^{18}$ The enumeration of witnesses is a part of the formulary of the document as one of the ways of its verification. Testimony also includes supervision, therefore the recipient of the document was not indifferent to the names introduced into the eschatocol. Under the conditions of oral culture, very few recipients could read; at the same time the imperfection of administrative structures made the implementation of the charters almost entirely a problem of the recipient. Witnesses were just that institution to which one applied if any difficulties arose concerning the implementation of a particular charter.

However, in this case the 'view from the recipient's perspective' is marginal. Much more important is the aspect of the informational nature of the testationes. They reveal the circle of the people accompanying the ruler in his permanent progresses which were commonplace in the activity of any medieval sovereign. Simultaneously, they indicate the most influential people of the state. Being next to the ruler was the only chance to influence resolutions and be among those counsellors (consiliarii, rath), whose advise is taken into consideration; consequently it is hardly possible to distinguish between the retinue of the ruler and the ruling élite.

The lists of the witnesses in the documents of the Lithuanian grand dukes specify a group of people, making up the élite echelon of the noble society of the time. The data obtained from other sources show that the testationes reflect the real situation in the governing of the state quite adequately, suggesting only some minor corrections of the entire picture. It became clear that the social

17 Thus, in the complaint against Jogaila and Skirgaila ('Dis ist Witoldes sache wedir Jagaln und Skirgaln') Vytautas resented the way his followers were treated by Jogaila: ' ... und was do y woren myner vrunde von allen nam Jagal ire fetirlich erbe'. K. Alminauskis, 'Vytauto skundas', Archivum Philologicum, 8 (1939), p. 215.

18 M. Kosman, 'Dokumenty wielkiego księcia Witolda', Studia Źródłoznawcze, 16 (1971), pp. 139-168. 
composition and structure of the members of the ruler's court did not undergo any changes. ${ }^{19}$ The chronological differentiation of the material does not attest any sudden change in the composition of the ruling élite. In the period under review a gradual increase of the influence of individual persons becomes obvious; interestingly, the mention of father and son or uncle and nephew is very rare in the same lists. The representatives of the same families occur in the lists. The stability of the composition of the high nobility shows the hereditary nature of this social stratum. As has been indicated above, the sources do not display the genealogical ties of the earlier period. The continuity of the high nobility can be traced back only to the latter half of the fourteenth century. The high noblemen of Vytautas' time, however, can already be characterized definitely as noble descendants, at the same time preserving that high status for their children. Thus, data from testationes do not confirm the hypotheses, frequent in historical literature, about a new social layer formed by Vytautas, or about the role of the Treaty of Horodło in the formation of that stratum.

Neither did the situation change in the subsequent decades of the fifteenth century. The same could be said about the rule of Vytautas' brother Žygimantas Kęstutaitis (r. 1432-1440), whose name is associated with the protection of the lower and middling nobility demonstrated both by the later tradition and modern historiography. The most comprehensive specimen of this tradition is the story about the murder of Žygimantas, presented in the Bychowiec Chronicle (the third decade of the sixteenth century). The murder is justified in the Chronicle due to Žygimantas' intention to annihilate the nobility. ${ }^{20}$ The story is not original, it is a compilation grounded in Russian and Polish sources and supplemented with local episodes. Researchers have noted that the organizers of the murder also had their share in the wording of the cycle of the stories, and that could not but affect its value as a historical source. ${ }^{21}$ It is not worth denying Žygimantas' cruelty, attested by other chroniclers as well; nevertheless, the information of such an unreliable source is insufficient to prove the extermination

${ }^{19}$ On the results of the research, see R. Petrauskas, Lietuvos diduomene XIV a. pabaigoje-XV a.: sudetis - struktūra - valdžia. Unpublished doctoral thesis, University of Vilnius, 2001.

20 Polnoe sobranie russkikh letopisei: xxxii. Khroniki: Litovskaia $i$ Zhomoitskaia, i Bykhovtsa (Moscow, 1975), pp. 155-156.

${ }^{21}$ K. Chodynicki, 'Geneza i rozwój podania o zabójstwie Zygmunta Kiejstutowicza', Ateneum Wileńskie, 5 (1928), pp. 79-103. 
of the élite of the nobility (or merely the preparation for it). In Žygimantas' time, the composition of the witnesses remained invariable. E.g., at the fidelity oath of Žygimantas Kęstutaitis to King Władysław III on 6 December 1437 the following witnesses were present: Bishop Matthew of Vilnius, Astikas, Castellan of Vilnius, Daugirdas, Palatine of Vilnius, and Kęsgaila Valmantaitis. ${ }^{22}$ All of them had been known since Vytautas' times and their high positions were in no way related to the sympathies of the new duke. Kęsgaila, in particular, could not be attributed to the favourites of the ruler. On Žygimantas' orders his brothers Jaunius and Rumbaudas were killed, and he himself lost the post of the Starosta of Žemaitija for the participation in the plot late in $1432 .{ }^{23}$ Kęsgaila's name is to be found in all the lists of the witnesses in the documents of the duke during Žygimantas' entire rule; and even certain diplomatic missions were entrusted to him. Jurgis Gedgaudas, having formerly sided with Švitrigaila, was also among the witnesses until his death in $1435 .{ }^{24}$ Such tolerance of the ruler in respect to his subjects could be accounted for only by the power of a social control mechanism, ensuring a person a sense of stability in the face of harsh reality.

The nobility, to be more precise, its cream, was the actual social and political authority in Lithuanian society in the fourteenth and fifteenth centuries. Based solely on official documents, the theory of the rise of the nobility in the fifteenth century does not take into account the incongruence between legal status and actual social position in contemporary society. There already existed a group of people, the belonging to which was predetermined by the inheritance of that particular social status. The legal formalization of that status was of lesser importance, not affecting the established relationships. A part of this nobility was descended from the former tribal aristocracy. A presumption of its eradication or demise is doubtful. ${ }^{25}$

22 Akta unji Polski z Litwa 1385-1791 (henceforth $A U$ ), ed. S. Kutrzeba and W. Semkowicz (Cracow, 1932), p. 108.

23 Liv-, Est- und Curländisches Urkundenbuch (henceforth LUB), ed. F. G. Bunge et al., VIII (Riga-Moscow, 1884), p. 373. More on that, see K. Pietkiewicz, Kieżgajłowie, pp. 16-18; R. Petrauskas, 'Giminaičiai ir pavaldiniai: Lietuvos bajoru grupès XIV a. pabaigoje-XV a. pirmoje pusèje', Lietuva ir jos kaimynai. Nuo normanu iki Napoleono. Prof. Broniaus Dundulio atminimui, ed. I. Valikonyte (Vilnius, 2001), pp. 112-116.

${ }^{24}$ Cf. Peltz, Ród Giedygotda, pp. 23-27.

${ }^{25} \mathrm{Cf}$. similar German and Polish considerations, F. Irsigler, Untersuchungen zur Geschichte des frühfränkischen Adels (Bonn, 1981), pp. 79-81; J. Bieniak, 'Rody rycerskie jako czynnik struktury społecznej w Polsce XIII-XV wieku (Uwagi problemowe)', Polska w okresie rozdrobnienia feudalnego, ed. H. Łowmiański (Wrocław, 1973), pp. 171-175. 
The issue of the nature of its descendants' power is problematic. An abstract question could be formulated like this: was the power of the nobility determined by its rights, deputed by the duke, or did nobles exercise those rights per se?

The Officials In this context it is important to investigate the bases for the authority of the fifteenth-century officials, in particular of the local ones. Lists of officials in the late fourteenth and early fifteenth centuries testify that there was a correlation between officeholding and relationship ties of officials. ${ }^{26}$ Sudivojus Valmantaitis was replaced by his nephew Mykolas Kęsgailaitis in the post as chancellor. Rumbaudas Valmantaitis, his nephew Stankus Sudivojaitis and their relative Martynas Goštautas were grand marshals. This sort of dependence was particularly noticeable in local posts. After his death the first palatine of Vilnius, Albertas Manvydas, was replaced by his brother Jurgis Gedgaudas. The continuance was interrupted, Gedgaudas siding with Švitrigaila. The family tradition was continued by Jonas Goštautas' becoming palatine in 1443; his father Andrius had been the capitaneus (lieutenant) of Vilnius in 1387. He was succeeded by Mykolas Kęsgailaitis; one sister of his was married to Jonas Goštautas and the other to Petras Senka Gedgaudaitis. Jonas Mantvydaitis' daughters were the wives of the last but one and the last Vilnius palatine of the fifteenth century Alekna Sudimantaitis and Jonas Manvydaitis. The issues of the personal identities of the starostas are still more interesting, since among other things, they were related to the geographical setting of patrimonies.

An analysis of the composition of the officials reveals the importance of family ties for the rotation in the posts. One's relationship with the predecessor was not a categorical condition to get a particular post. The grand duke, who enjoyed the right to appoint officials, could offer a vacant post to an outsider, and he did that more than once. However, frequent cases of post inheritance (a great number of them remains undisclosed, since the origin of the wives of many nobles could not be identified) demonstrate that the sovereign, as a rule, was not interested in changing time-honoured practice, particularly in regard to local authorities. ${ }^{27}$

${ }^{26}$ R. Petrauskas, 'Ponas savo žemëje: Lietuvos pareigūnai XIV a. pab.-XV a.', Lietuvos istorijos metraštis 2001/1 (Vilnius, 2002), pp. 9-30.

${ }^{27}$ For the analysis of individual cases, see ibid. 
Taking into consideration the situation of the power functioning in medieval Lithuania, this kind of policy of the grand duke becomes understandable. Due to the absence of an administrative structure covering the entire country, the grand duke made regular voyages throughout the country, thus consolidating his power in the provinces. $^{28}$ Not being able to control that power constantly, he inevitably had to rely on the local nobility. Therefore he could hardly be interested in destroying established hierarchical relations in the lands, powiats and districts. It was more sensible to exploit those relations in creating his own 'state' system of government. He established 'secondary' political institutes, which, for the sake of convenience, usually merged with primary state institutions. Thus, one could speak about a dual character of the lieutenancy - the duke's rule was based on the already existing socio-political relations.

In his work Wigand of Marburg, a chronicler of the Teutonic Order, writes about a force of 400 Lithuanians led by Busko in the land of Maišiagala in $1365 .^{29}$ Such a unit, though it was led by a local commander, most probably could not act without the duke's knowledge. For 1385 the Wegeberichte of the Order mention Busekindorf in the neighbouring land of Deltuva. ${ }^{30}$ One of the then key powiats, that of Ašmena, was ruled by Mingaila, whose patrimony was nearby. Kęsgaila, whose mother seems to have been born into a local noble family, was appointed Starosta of Žemaitija. This kind of logic in the appointment of officials is reflected in an episode of the chronicle in relation to a new elder of Žemaitija. Jonas Goštautas advises Casimir that he should replace the incumbent elder by his relative Kontautas. ${ }^{31}$ Scholars consider this story reliable; in any case, it is useful as a text, revealing the political consciousness of the time. It can be maintained that the surest successors to the post of the elder were his relatives, and that sort of practice was considered legitimate. It can also be stated that in the territories under their rule the elders could have their allodial lands. Doubtless, the ruler could find many ways of caring for the people committed to him, but his choices in selecting officials were

28 A. Gąsiorowski, Itinerarium króla Władystawa Jagietly 1386-1434 (Warsaw, 1972).

${ }^{29}$ SRP, II (Leipzig, 1863), p. 554.

${ }^{30}$ Ibid., p. 694; see also W. Semkowicz, 'O litewskich rodach zbratanych ze szlachtą polską w Horodle r. 1413', Rocznik Towarzystwa Heraldycznego, 7 (1924 1925), pp. 7-13; Pietkiewicz, Kieżgajłowie, pp. 13-28.

${ }^{31}$ Lietuvos metraštis: Bychovco kronika, ed. R. Jasas (Vilnius, 1971), p. 131. 
not limitless. A person outside the nobility could hardly cope with the representation of the ducal rule, and the problem of 'institutional vacuum' was permanent. The sources of the early fifteenth century do not contain any evidence of the existence of a group of persons subject to the elder. Naturally, a question arises as to who/what could be the base of his authority. Given a permanent external danger, that could be a burning issue. Reliable support could be expected only from relatives and allies, in the sources referred to as amici, frunde or priiateli. The allies did not differ much from the relatives. Social relations, based on 'friendship', practically replicated the model of relationship ties - horizontality was typical of both types. It was a kind of extended relationship. In the sources these terms could be used to denote ties of blood as well.

The historiographically dominating viewpoint that the Gediminid dukes created the service nobility which afterwards underwent emancipation ('the submissive character of the Lithuanian nobility'), oversimplifies the social and political relationships of Lithuanian society. People without posts could also belong to the ruling élite (e.g., Mingaila in the early fifteenth century), and their hierarchical degrees could not necessarily match the gradation of the posts, known in later times (the prime person was the palatine of Vilnius and chancellor of the GDL, etc.). Thus, in 1387 doubtless the most influential nobleman was the Starosta of Ašmena (sic). In 1440, Jonas Goštautas, lieutenant of Smolensk, and Kęsgaila, Jonas Manvydaitis, Radvila Astikaitis and Mikalojus Nemiraitis, nobles in minor posts, played a crucial role in the nomination of Prince Casimir to the Lithuanian throne. As it is attested by the further careers of some aforementioned persons, the post hierarchy was in the process of developing at that time; that situation, however, cannot be projected to former times.

Kinship In the structural analysis of the nobility, family relationships are of major significance. On this issue the debate between Polish historians Władysław Semkowicz and Oskar Halecki was particularly influential. ${ }^{32}$ The originator of the Polish school of genealogy, Semkowicz, was consistent in the defence of his theory of the structure of the kindred Lithuanian nobility, grounding it in

32 W. Semkowicz, 'W sprawie początków szlachty na Litwie i jej ustroju rodowego', Kwartalnik Historyczny, 29 (1915), pp. 224-256; O. Halecki, 'O początkach szlachty i heraldyki na Litwie, ibid., 30 (1916), pp. 177-207; idem, 'Kwestje sporne w sprawie początków szlachty litewskiej, ibid., pp. 62-72. 
a number of studies of the 'Horodlian' Lithuanian stirpes. Despite many interesting observations on various aspects of family relations, he failed to counteract some of Halecki's arguments. The latter justly criticized a forthright presentation of the society of the times of Jogaila and Vytautas in terms of the primeval kinship structure. Indeed, the sources do not show any traces of a unified, closed and politically effective kinship organization. This critique, however, was conditioned by the opponent's theses. Turned on criticism, Halecki failed to notice that he was moving in the circle of notions, described by his opponent - either the primeval kinship unit or the family - and not referring to the possibility of the evolution of the kinship structure at least in the form of a hint. ${ }^{33}$

Jerzy Suchocki's study is devoted to the issues of the internal structure of the Lithuanian nobility in the fifteenth century. ${ }^{34}$ In his opinion, in Vytautas' time we are dealing with separate noble families. The coats of arms, received at Horodło, were used individually. The terms stirps, cognatio and genelogia, occasionally applied to the groups of these people, do not adequately reflect contemporary Lithuanian reality. In order to substantiate his theory, he ignored many reliable genealogical ties. Thus, he neglected to mention that the Palatine of Vilnius Albertas Manvydas and Jurgis Gedgaudas were brothers and spoke about their common use of the Leliwa coat of arms very indistinctly. ${ }^{35}$ None the less, in a letter of the Grand Duke Švitrigaila, addressed to the Livonian Master, Jonas Manvydaitis was referred to as Gedgaudas' nephew (nepos). ${ }^{36}$ Many similar cases of the joint use of the same coat of arms by the members of the same family or kin already in the first decades after the Horodło Agreement could be easily indicated. It is evident that the hypothesis of the rise of new aristocratic families in Vytautas' times is not factographically irreproachable. An artificial classification by families of the high nobility would have been incomprehensible to the people of that time. In a letter to the Master, dictated in a desperate situation (two days before the coup), Švitrigaila somehow did not fail to indicate the kin relationship between Jurgis Gedgaudas and Jonas Manvydaitis.

${ }^{33}$ The further characteristics of the nobility structure are based on Petrauskas, 'XV amžiaus Lietuvos bajorijos struktūra: giminès problema', Tarp istorijos ir būtoves. Studijos prof. Edvardo Gudavičiaus 70-mečiui, ed. A. Bumblauskas and R. Petrauskas (Vilnius, 1999), pp. 123-158.

34 J. Suchocki, 'Formowanie się', pp. 43-59.

${ }^{35}$ Ibid., p. 52.

${ }^{36}$ LUB, VIII, p. 366 (Polotsk, 3 Sept. 1432). 
In such a case, what did the terms cognatio, genelogia, stirps and domus, applied to the participants of the treaties of Vilnius-Radom (1401) and Horodło (1413), stand for? ${ }^{37}$ They cannot be translated as 'family'. Even the Latin word familia had many connotations at that time, denoting 'an extended unfree family', 'people living under the same roof', etc. The only more suitable equivalent of those terms would be 'kin'; however, its meaning needs to be disclosed.

In studies by Western medievalists the 'open kinship structure' of the Middle Ages is seen as differing both from the relations of the age of primitive society and from the later agnate kinship. ${ }^{38}$ The kinships of those times were not legally defined static units. They were constantly changing structures, in which the matrilineal relatives could be as influential as the patrilineal ones. Their kinship structure could not be stable, because each generation existed in a different consanguineous constellation. The same should be said about land owning - the size and structure of the estates changed with each new division, marriage, or inheritance. Under such conditions inherited family names could not appear, and that is what is mostly missed by the critics of kinship significance, in addition to substantial long-term family seats.

It must always be borne in mind that such concepts as 'the Gediminids' or 'descendants of Algirdas' were used by the contemporaries only in reference to their direct descendants, while their extrapolation is a concern of the historians. The absence of an inherited name offers important reference for the study of the kinship structure and kinship self-consciousness. In this self-consciousness the functioning of such a significant genealogical aspect, so close to kinship, seems to have been weak. The earliest historical tradition of Lithuanian rulers can serve as an example, corroborating that statement. The Chronicle of the Grand Dukes, created in Vytautas'

${ }^{37} A U$, pp. 38, 54.

${ }^{38}$ K. Schmid, 'Zur Problematik von Familie, Sippe and Geschlecht, Haus und Dynastie beim mittelalterlichen Adel', Zeitschrift für die Geschichte des Oberrheins, 105 (1957), pp. 1-62; idem, 'Über die Struktur des Adels im früheren Mittelalter', Jahrbuch für fränkische Landesforschung, 19 (1959), pp. 1-23; G. Duby, 'Lignage, Adel und Rittertum im 12. Jahrhundert in der Gegend von Macon', Schrift und Materie der Geschichte (Frankfurt am Main, 1977), pp. 415439; G. Althoff, Verwandte, Freunde und Getreue. Zum politischen Stellenwert der Gruppenbindungen im früheren Mittelalter (Darmstadt, 1990). On a slight modification of this theory, see W. Störmer, Früher Adel: Studie zur politischen Führungsschicht im fränkisch-deutschen Reich vom 8. bis 11. Jahrhundert (Stuttgart, 1973), pp. 40-45, 92 ff.; K.-H. Spieß, Familie und Verwandtschaft im deutschen Hochadel des Spätmittelalters. 13. bis Anfang des 16. Jahrhunderts (Stuttgart, 1993), pp. 494-531. 
circle and starting 'Vytautas' history' with his grandfather Gediminas, does not speak about former times. That cannot be accounted for by the fact that Gediminas' origin was found unacceptable by his descendants, because the historians were quite sure that at least Gediminas' father must have been Lithuania's ruler. The contemporary people possibly did not need to know their predecessors more distant than grandfathers, because their existing state could not be changed by such remembrances.

Very informative is the name system of the Lithuanian nobility. In the late fourteenth century the type of compound names (name + patronymic) becomes established. In the records Valmantas is referred to as Busko's son. His sons such as Jaunius, Rumbaudas, Kęsgaila and Sudivojus added the patronymic 'Valmantaitis' to their given names, and their sons were Mykolas Rumbaudaitis, Jonas and Mykolas Kęsgailaitis, Stankus Sudijovaitis, etc. The contemporaries called Jonas Kęsgailaitis' sons Stanislovas and Mykolas Jonaitis, though the introduction of 'Kęsgailaitis' into the name would have made it more reputable than a common patronymic 'Jonaitis' ${ }^{39}$ Nevertheless, the thinking was different. According to simultaneous sources the references to persons of different generations as 'Kęsgaila/Kęsgailaitis', Mangirdas/Mangirdaitis' or 'Sakas/Sakaitis' are of a late date. The Goštautas case is exceptional they acquired their hereditary name very early. The sources do not show the genesis of this tradition; that name could have been affected by the relationship with the Polish nobility.

The tradition of such names provides a clue for the definition of kinship self-consciousness. Firstly, it was a 'horizontal' rather than a 'vertical' self-consciousness, when ignoring the ancestors, relatives by marriage and other secondary lines of the same generation are approved. No cultural form has been observed, which could have recorded a person's past. Especially important was the absence of the culture of writing, since the transmission of information about a particular event in oral tradition was very unreliable. The Lithuanian chronicles of the early sixteenth century do not record, but recreate the historical tradition of Lithuanian noble families. The basic technique of the authors was a combination of compilation and fiction as well as the amplification of the previous information by new stories, consonant with the contemporary interpretation of the events described.

${ }^{39} K D K D W$, pp. 348, 443, 516, 748-749; $A U$, pp. 38, 127. 
The 'horizontality' of the family should not be taken too strictly, since primarily it was a not a biological, but a social category, the essence of which was conditioned by specific self-identity. It was based on a certain selection of relationship preservation and development, paying great attention to the matrilineal line. The desire to marry off all girls was conditioned by the fact that a person's high status to a great extent was inherited through the mother. Sadly, the sources do not offer information on the names of the mothers of the nobles of Vytautas' time and very infrequently indicate the names of their wives and daughters. Nevertheless, even these rare cases attest to the importance of contacts established through women. The rise of Sudimantas and Jonas Alšèniškis is to be accounted for not so much by their princely descent, but by his being a brother-in-law of Vytautas (no matter how far removed). ${ }^{40}$ The origin of Manvydas' wife doubtlessly affected his career. His brother Jurgis Gedgaudas also married a duchess. ${ }^{41}$ The second wife of Petras Mangirdaitis was Ona, a daughter of the Gediminid duke Teodoras Kaributas. ${ }^{42}$

Such extended families were not particularly numerous; however, some common grants show that their composition included more than brothers and cousins. The main functions of the family were the preservation of the social status, personal protection and memory. The political coordination with the family remains undisclosed. The ruling Gediminid dynasty could hardly tolerate closed politically effective communities. The developing system of posts had to destroy them from within, and the transformation of the 'open-kinship' structure' into a strictly structured agnate noble family, recognizing only men as inheritors, was pre-programmed.

The first traces of this change, as could be expected, are seen in the family of the dukes. It was Gediminas who divided the country among his seven sons. ${ }^{43}$ Meanwhile in the times of Algirdas and Kęstutis the situation underwent radical changes. The rule of one son (not always of the first-born) gradually became predominant. The secondary kinship lines were divorced from government. The

40 J. Tęgowski, 'Małżeństwa księcia Witolda Kiejstutowicza', Rocznik Polskiego Towarzystwa Heraldycznego, new series, 2(13) (1995), pp. 177-182.

${ }^{41}$ Petrauskas, 'Vytauto laikų didikų kilmė', p. 17.

42 W. Semkowicz, 'Łosk i wygaśnięcie Kaributowiczów', Rocznik Towarzystwa Heraldycznego, 7 (1924-1925), pp. 197-209.

${ }^{43} \mathrm{Cf}$. the most recent work of the Gediminid genealogy, J. Tęgowski, Pierwsze pokolenia Giedyminowiczów (Poznań-Wrocław, 1999). 
example of the dukes could be a lesson for the nobility. Sparse fifteenth-century sources do not reveal the fate of the descendants of many nobles, though in some cases the lack of information can lead to certain conclusions. Again, the history of the Goštautas family is instructive. ${ }^{44}$ In it a correlation between the existence of a stable name and a fresh policy of the family could be seen. Several Goštautas representatives are known in every generation (Jonas, Talvaiša and Petras - Andrius Goštautas' sons; Martynas, Albertas and Jurgis Jonas Goštautas' sons), only one of them usually had descendants, and that doubtlessly led to the concentration of the family's power. It is difficult to say whether that was a conscious matrimonial policy or only merely the extinction of the family. Some details of the biographies of the children of Jonas Goštautas, the most influential Lithuanian nobleman of the fifteenth century, suggest an assumption of a conscious strategy. His son Jurgis became a clergyman. Thus, the opportunities offered by the Church were exploited to accommodate the sons not destined for marriage. One of the daughters, Marija, was married to Simonas Olelkaitis, a duke of Gediminid descent, and the other, Marina, to the nobleman Jonas Kučukaitis. ${ }^{45}$ The third daughter, Aleksandra, entered a convent. It could be surmised that in the absence of a suitable partner no attempts were made to marry the daughters off at any hazards rather than leave them unmarried. Thus, the division of larger possessions was avoided. Namely this sort of matrimonial policy eventually secured the concentration of land in the hands of one representative of the family (a most remarkable example is Albertas Goštautas, the most influential Lithuanian nobleman of the early sixteenth century), although, on the other hand, that increased the danger of the demise of a genealogical line - and that was just the case of the Goštautas in 1542 .

A wide web of kinship connections, which formerly conditioned the power of the family, became less relevant. The thirteenth-century Livonian Rhymed Chronicle, emphasizing the authority of the Liv Caupo, stated that his family was large. ${ }^{46}$ The late-fifteenth-century state structures took over many functions, which previously could be performed only by the relatives. In the process of the transformation some families (the Goštautas, Kęsgailas and Radvilas) managed

${ }^{44}$ For the Goštautas genealogy, see M. Kuźmińska, 'Olbracht Marcinowicz Gasztołd', Ateneum Wileńskie, 4 (1927), pp. 349-391; 5 (1928), pp. 120-174.

45 Bullarium Poloniae, ed. I. Sułkowska-Kuraś, S. Kuraś, VI (1447-1464) (Rome-Lublin, 1998), p. 258.

${ }^{46}$ Livländische Reimchronik, ed. L. Meyer (Paderborn, 1876), p. 9 ( $\sin$ geschlechte daz ist breit). 
to retain their power and property, while others (the Sakaitises and Sviriškises) failed to maintain their status.

The structure of the nobility also underwent changes: power and property increasingly were concentrated in one branch. Eventually genealogical self-consciousness was developing - the noblemen began searching for their roots, tracing family histories in the past as far as possible through patrilineal ancestors. The fifteenth century was only the beginning of that process. The principle of primogeniture had still to take on an added importance. The ability to preserve the holdings of the family from partition was crucial for the retention of the socio-political significance of the family. A partial implementation of the system of primogeniture could possibly be decisive in the setback of the high nobility in the reforms of the mid-sixteenth century.

This research has shown that in the fourteenth and fifteenth centuries there existed a personal continuity of the Lithuanian high nobility. Simultaneously, a transformation was taking place, which brought about significant changes in the social structure of this layer, despite the existence of the descendants of the fourteenthcentury nobles in the élite echelons of the fifteenth century.

The power of the nobility co-existed side by side with that of the grand duke. The rivalry in the Gediminid dynasty created conditions for the manifestation of the strength of purpose of the nobles. This rivalry, as well as the ties of relationship, conditioned the composition of the nobility groups. ${ }^{47}$ During the protracted rule of Casimir Jagiellonczyk (1440-1492) the changes in the ruling dynasty and in the nobility influenced both the modification of the principles of group formation and, what was more important, the consolidation of the ruling élite. The rise of estate structures (the Council of Lords) was a basis on which the Lithuanian magnates could co-ordinate their interests. ${ }^{48}$

${ }^{47}$ On the composition of the groups and the principles of their functioning, see S. C. Rowell, 'Bears and traitors, or political tensions in the Grand Duchy ca. 1440-1481', Lithuanian Historical Studies, 2 (1997), p. 7 ff.; Petrauskas, 'Giminaičiai ir pavaldiniai', pp. 107-126.

${ }^{48}$ About the instutionalization process of the council of the grand duke, see Korczak, Litewska rada, pp. 10-22; Pietkiewicz, Wielkie Księstwo Litewskie, pp. 80-84, 108-124. It is noteworthy that about the middle of the fifteenth century the concept 'the council of the grand duke' is often replaced by a new concept 'the Council of the Grand Duchy of Lithuania'. On 28 May 1455 the Lithuanian nobles sent a letter as totaque communitas consilii terre ducatus magni Littuanie (Geheimes Staatsarchiv Preußischer Kulturbesitz, Ordensbriefarchiv 13725). In 1459 the burghers of Danzig address their letter to den rethen des forstenthums czu Lithawen. -Hansisches Urkundenbuch, ed. W. Stein, 8 (Leipzig, 1899), p. 475. 
The representatives of the high nobility continued their rivalry for higher status, and at the same time, in the second half of the fifteenth century they began to perceive themselves as members of one and the same estate.

\section{Author Details}

After graduation from the Faculty of History of the University of Vilnius, Rimvydas Petrauskas did his postgraduate studies at the universities of Basel (1995-1996), Greifswald (1999) and Berlin (2000). In 2001 he defended his doctoral thesis on the Lithuanian nobility. At present Petrauskas teaches history at the University of Vilnius. His sphere of research is political and social history of Lithuania in the 15 th and 16 th centuries.

Address: Faculty of History, University of Vilnius, Universiteto 7, LT-2002 Vilnius, Lithuania

Email: rimpet@takas.lt

\section{LIETUVOS DIDUOMENĖ XIV A. PAB. - XV AMŽIUJE: SUDĖTIS IR STRUKTŪRA}

\section{Santrauka}

\section{RIMVYDAS PETRAUSKAS}

$\mathrm{XIV}-\mathrm{XV}$ a. istorija lietuvių istorinèje savimonejje yra igijusi „kunigaikščiu Lietuvos“ ivvaizdị. Šie amžiai - tai visų pirma Gedimino, Algirdo, Kęstučio, Jogailos, Vytauto laikai. Iš dalies toks požiūris yra teisingas, kadangi viduramžiais valdovas simbolizavo, ikūnijo pačią valstybę. Valstybė buvo laikoma valdovo tėvonija, o visi jos gyventojai - jo valdiniais. Šis idealus tos epochos modelis istoriografijoje buvo paverstas aiškinamaja koncepcija. Tačiau norint adekvačiai suvokti viduramžių socialinị ir politini gyvenimą, būtina pažinti visuomenès grupę, kuri konkuruodama ir bendradarbiaudama su kunigaikščiais formavo tos epochos gyvenimo tvarką. Šiame straipsnyje pristatomi XIV a. pabaigos - XV a. aukščiausio lietuvių bajorijos sluoksnio - diduomenès - tyrimo rezultatai. Straipsnyje nagrinèjama diduomenès sąvoka, jos sudètis, kilmè, struktūra, valdžios prielaidos. Mėginama parodyti, kad istoriografijoje vyraujantis didžiojo kunigaikščio sukurtos diduomenès vaizdinys pernelyg supaprastina tuometinius sociopolitinius santykius. Pamažu aiškẻja, kad diduomenès valdžia buvo savito proceso rezultatas, kuriame valdovo valia tebuvo vienas faktorius tarp daugelio kitų. Taip teigti visų pirma leidžia lietuvių diduomenès personalinis tęstinumas XIV-XV a. Diduomenès sudèties stabilumas patvirtina paveldimą šio socialinio sluoksnio prigimtį. Kita vertus, XV a. vyko diduomenès transformacija, iš esmès pakeitusi šios socialinès grupès struktūrą. Kuriantis naujoms valstybinèms institucijoms, ịsigalint pareigybių sistemai, neišvengiama buvo senosios giminès transformacija į griežtai struktūruotą agnatinę giminę, kurioje dominavo vyriška paveldejjimo linija. Ši transformacija susijusi su valdžios koncentracijos procesu atskirose didiku giminių šakose, o ją atspindi paveldimu giminès vardų (,,pavardžių“) bei genealoginès savimonès atsiradimas. 